\title{
Thermal methods implementation in analysis of fine-grained rocks containing organic matter
}

\author{
Małgorzata Labus ${ }^{1}$ (D)
}

Received: 4 February 2016/Accepted: 6 March 2017/Published online: 15 March 2017

(C) The Author(s) 2017. This article is published with open access at Springerlink.com

\begin{abstract}
The thermal methods, including TG and DSC techniques, were implemented to determine the composition of the fine-grained rocks with dispersed organic matter. The analyses were carried out in inert and oxidising atmosphere. The analysed samples represented Palaeozoic siltstones, shales, claystones and mudstones from Baltic Basin, Lublin Basin and Upper Silesian Coal Basin (Poland). There was detected the presence of some minerals as: clay minerals, muscovite, quartz, calcite, dolomite and pyrite. A comparison of the reactions occurring in an oxidising and inert atmosphere can give a solution to the problem of some effects overlapping, such as distinguishing pyrite decomposition from organic matter combustion. The analysis of DSC curves of heated rocks under oxidative atmosphere allows to determine the temperature regions of the organic matter combustion and to conclude on its maturity level. There was also found a strong correlation between the mass loss resulted from organic matter combustion, and the mass loss as a result of pyrolysis.
\end{abstract}

Keywords Thermal analysis - Shale - Organic matter · Pyrolysis

Małgorzata Labus

malgorzata.labus@polsl.pl

1 Institute for Applied Geology, Silesian University of Technology, 2 Akademicka St., 44-100 Gliwice, Poland

\section{Introduction}

The aim of the study was to determine the composition of the fine-grained rocks with dispersed organic matter, using thermal methods, including differential scanning calorimetry (DSC). In the examinations of shale rocks, including gas shales, for determining their productivity, the type of kerogen, and its level of thermal maturity, is of primary importance. Organic matter content in shales or silty shales is an indicator of potential hydrocarbon source rocks. Gas shale contains predominantly Type II kerogen, as opposed to coal and coal bed methane reservoirs, which contain mostly Type III. Kerogen is the main source of TOC in the rock; hence, they are usually correlated.

The thermal methods, including TG, DSC and DTA techniques, are implemented in evaluation of fossil fuels: lignites [1], coal [2, 3] and oil shales [4-6], etc. Rajeshwar $[7,8]$ stated the applicability of DSC method to measurement of oil shale combustion enthalpies.

Organic matter in sedimentary rocks is usually present in two different forms: finely disseminated macromolecular material (kerogen, insoluble in usual organic solvents), and free hydrocarbons (bitumen, soluble in usual organic solvents) [9]. In the case of rocks of a lower organic matter content, interpretation of the results of thermal analysis encounters certain difficulties, due to the complex mineral composition [10, 11]. The presence of organic matter in rocks containing clay minerals (due to their sorptive properties) shifts the characteristic peaks temperature range for the various types of minerals. Therefore, there were conducted comparative studies [12] on artificial mixtures of liquid and solid organic substances with various clay minerals. The most frequent and difficult problem identified by Paulik et al. [13] is that the individual mineral components decompose closely after one another. In this 
case, it is very helpful to implement an analyser of gases released as a consequence of the reactions. To avoid the problem of overlapping thermal effects, the thermal analysis experiments were also conducted on kerogen extracted from the studied rocks; regarding kerogen as a geochemical marker of the thermal history of rocks $[11,14]$.

\section{Samples and methods}

The analysed samples represent Silurian siltstones and shales (gas shale), as well as Upper Carboniferous claystones and mudstones, containing dispersed organic matter (Table 1).

Because of the complex mineral composition of the analysed rocks, there were performed microscopic examinations in transmitted light, and the XRD analysis of the phase composition.

For XRD analysis, the rock samples were ground in McCroneMicronisingMill to the granularity of less than $5 \mathrm{~mm}$ and were homogenised by micronising in a vibration mill and then pressed into the cells of depth of $2 \mathrm{~mm}$. XRD measurements were carried out with use of powder diffractometer Bruke-AXS Advance D8 (Germany) of 2 $\theta / \theta$ geometry, equipped with linear semiconductor detector LynxEye and energy-dispersive detector SOL-XE. Measurement conditions: radiation $\mathrm{CoK} \alpha / \mathrm{Fe}$ filter, voltage $40 \mathrm{kV}$, current $40 \mathrm{~mA}$, step of $0.0142 \theta$, step time $1.25 \mathrm{~s}$ (the sum of five measurements with a step of $0.25 \mathrm{~s}$ ) and digital processing of the resulting data. For the measurement and calculation, there was used software of BrukerDiffracSuite.

For qualitative assessment, the diffraction database PDF-2, version 2011 (International Data Centre for Diffraction, Pennsylvania, USA) was used. For semiquantitative analysis Bruker Topas version 4.2 software was implemented. Quantification is based on a Rietveld method of structural analysis of the powder diffraction data and consists in modelling diffraction spectrum using the known structural data (lattice parameters, the positions of atoms in the structure, space group, etc.) for each of the minerals and the subsequent comparison of the measured diffraction pattern using multivariate regression. The deviation between measured and calculated from the crystal structure record is treated as measurement error. Input structural data were taken from BrukerDiffracPlus Topas structure database.

In XRD analysis of rock samples, the internal standard ( $\mathrm{ZnO}$, cca $10 \%)$ was used. Quantitative analysis is possible by comparing the integral intensity of the reflections of individual minerals in the sample to the intensity of the standard $(\mathrm{ZnO})$ reflex. To determine the amount of amorphic components (including organic matter), the sum of crystalline components was substracted from $100 \%$. The example of XRD spectrum is shown in Fig. 1.

Total organic carbon content in the samples (TOC), which is generally regarded as an indicator of kerogen and bitumen amounts in the rock, was determined with use of the Rock-Eval pyrolysis method.

The essential part of the study was the analysis of mineral composition and organic matter content in the examined rocks, performed with use of thermal methods (TG/DSC). The experiments were performed with NETZSCH STA 449 F3 Jupiter ${ }^{\circledR}$ equipment. The measurement heating rate was $10 \mathrm{~K} \mathrm{~min}^{-1}$. The analysis of the rock samples was carried out over the temperature range of $40-1000{ }^{\circ} \mathrm{C}$, in the oxidising atmosphere (synthetic air) or under inert gas (nitrogen), with gas flow rate of $50 \mathrm{~mL} \mathrm{~min}{ }^{-1}$. The samples were powdered and put into the alumina $\left(\mathrm{Al}_{2} \mathrm{O}_{3}\right)$ crucible in amount of about $20 \mathrm{mg}$. Before the analysis, the instrument was calibrated using six temperature standards from $156{ }^{\circ} \mathrm{C}$ (indium) to $1064{ }^{\circ} \mathrm{C}$ (gold).

\section{Results and discussion}

\section{Curves interpretation}

As a result of performed analysis, there were obtained several curves (TG, DTG and DSC) for each sample, separately for oxidising (synthetic air) and inert $\left(\mathrm{N}_{2}\right)$ atmosphere.

The thermally active minerals, detectable in the analysed samples, are: clay minerals, muscovite, quartz, calcite, dolomite and pyrite. In the oxidising atmosphere, the intensive exothermic peak reflects organic matter combustion, whereas in inert atmosphere the weak endothermic peak is attributed to pyrolysis of the organic matter. The example of the curves interpretation is shown in Fig. 2 (sample 8). All of the determined reactions in examined samples are synthetically listed in Table 2. The temperatures of the thermal effect beginning and the end were determined as onset and endset on the DTG curves, whereas $T_{\max }$-on DSC curves. The notes with two values in brackets (e.g. 388-/453, 481/-550) mean that the thermal effect has two points of maximal temperature, as in the example of sample 1 (Fig. 2).

In the first segment of DSC curves (up to approx. $300{ }^{\circ} \mathrm{C}$ ) for each of the samples, the dehydration of clay minerals is shown by an endothermic peak, regardless gas atmosphere of the analysis. The term "clay minerals" in this case usually refers to kaolinite, but in some cases, when chlorites and micas (muscovite) are very fine-grained and dispersed in the rock, these minerals can also be manifested in dehydration segment of the curves. Usually 
Table 1 Stratigraphical position and mineral composition of the examined samples

\begin{tabular}{llll}
\hline Sample & Stratigraphical position & Region & Mineral content $($ XRD $) /$ mass $\%$ \\
\hline
\end{tabular}

$1 \quad$ Lower Silurian Lublin Basin

Quartz: 34.50

Muscovite: 37.33

Chlorite: 9.73

Microcline: 9.77

Dolomite: 2.24

Calcite: 2.39

Pyrite: 1.39

Amorphous: 2.65

2

Quartz: 90.54

Muscovite: 5,78

Albite: 3.34

Amorphous: 0.34

Quartz: 45.08

Muscovite: 34.41

Microcline: 12.05

Albite: 7.30

Amorphous: 1.12

Baltic Basin

Upper Carboniferous

Upper Silesian Coal Basin

Quartz: 36.96

Muscovite: 23.88

Chlorite: 12.36

Albite: 8.15

Dolomite: 7.30

Calcite: 5,40

Orthoclase: 3.51

Pyrite: 2.43

Amorphous: 19.70

Quartz: 25.60

Muscovite: 31.84

Chlorite: 10.12

Albite: 5.29

Kaolinite: 6.25

Amorphous: 20.90

Quartz: 24.80

Muscovite: 24.92

Chlorite: 10.08

Albite: 10.71

Amorphous: 29.50

Quartz: 35.56

Muscovite: 21.64

Chlorite: 6.47

Albite: 13.60

Orthoclase: 9.30

Amorphous: 9.30

Quartz: 28.12

Muscovite: 18.99

Chlorite: 1.47

Albite: 0.52

Orthoclase: 10.39

Amorphous: 31.1 
Table 1 continued

\begin{tabular}{|c|c|c|c|}
\hline Sample & Stratigraphical position & Region & Mineral content (XRD)/mass \% \\
\hline K2 & & & $\begin{array}{l}\text { Quartz: } 26.58 \\
\text { Muscovite: } 33.08 \\
\text { Chlorite: } 10.51 \\
\text { Albite: } 5.48 \\
\text { Kaolinite: } 6.43 \\
\text { Amorphous: } 17.90\end{array}$ \\
\hline P1 & & & $\begin{array}{l}\text { Quartz: } 28.71 \\
\text { Muscovite: } 30.39 \\
\text { Chlorite: } 2.69 \\
\text { Albite: } 2.11 \\
\text { Orthoclase: } 5.54 \\
\text { Kaolinite: } 18.66 \\
\text { Amorphous: } 11.90\end{array}$ \\
\hline Q22 & Upper Carboniferous & $x^{2}$ & $\begin{array}{l}\text { Quartz: } 28.97 \\
\text { Muscovite: } 23.88 \\
\text { Chlorite: } 6.77 \\
\text { Albite: } 5.63 \\
\text { Pyrite: } 1.71 \\
\text { Amorphous: } 33.00\end{array}$ \\
\hline R4 & & Upper Silesian Coal Basin & $\begin{array}{l}\text { Quartz: } 23.13 \\
\text { Muscovite: } 13.94 \\
\text { Chlorite: } 8.48 \\
\text { Albite: } 11.43 \\
\text { Orthoclase: } 9.94 \\
\text { Amorphous: } 20.40\end{array}$ \\
\hline R5 & & & $\begin{array}{l}\text { Quartz: } 25.79 \\
\text { Muscovite: } 18.66 \\
\text { Chlorite: } 6.39 \\
\text { Albite: } 10.75 \\
\text { Kaolinite: } 8.70 \\
\text { Siderite: } 3.20 \\
\text { Amorphous: } 26.00\end{array}$ \\
\hline
\end{tabular}

the maximum of the reaction is well visible on DTG curves, and it is placed between 70 and $115^{\circ} \mathrm{C}$. The size of DSC peak is often smaller than it could be expected, taking into account the clay minerals content detected by other measurements. Yariv [12] explains this state by the presence of organic matter which replaces some of the adsorbed water in clay minerals. Moreover, the presence of organic molecules on the clay surface makes it hydrophobic, and, consequently, the peak of the maximum appears at a lower temperature.

In the range of temperatures from 300 to $700{ }^{\circ} \mathrm{C}$, the shape of DSC and TG curves depends on the implemented atmosphere. In oxidising environment (synthetic air), the oxidation (combustion) of organic matter takes place. The several exothermic peaks are observed on the curve. In some cases, certain reactions are overlapping and the distinction is not possible. The fine-grained Palaeozoic rocks very often contain sulphides (mostly pyrite), which reactions interfere the organic matter oxidation. In an oxidising atmosphere, the thermal evolution of pyrite is complex, and it is the combination of oxidation, decomposition and thermal dissociation [15]. The most characteristic feature of pyrite presence in the rock sample is a strong exothermic reaction in range of $400-550{ }^{\circ} \mathrm{C}$, and relatively small effect of mass loss.

In case of rich in organic matter shales, when they are heated in an inert atmosphere, the two different mechanisms causing loss of mass are visible. According to Marshall et al. [10] in the temperatures higher than $600{ }^{\circ} \mathrm{C}$, the first mechanism is distillation, and the next is thermal cracking. In case of our samples, under inert atmosphere (nitrogen) the weak endothermic peaks attributed to pyrolysis of the organic material is placed in range of temperature from 310 to $660{ }^{\circ} \mathrm{C}$. The maximum 

spectrum (sample C2)
Fig. 1 Example of XRD

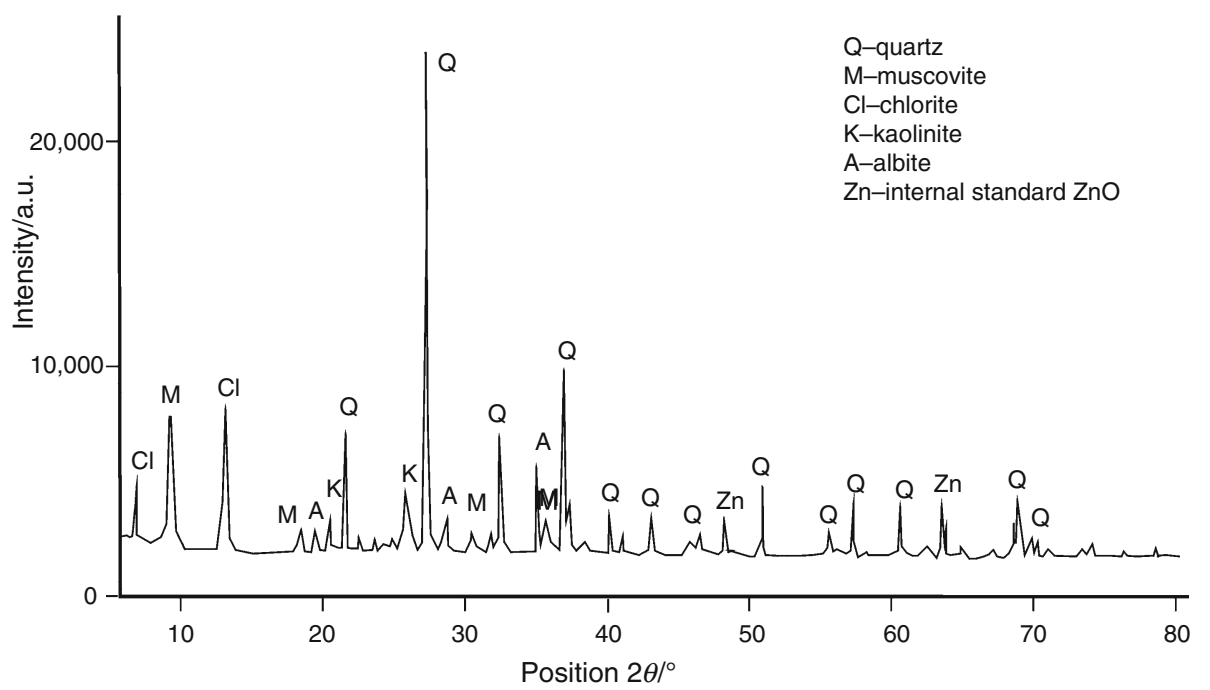

Fig. 2 DSC, TG and DTG curves for sample 8 (oxidising atmosphere). First step on TG curve (with no distinct maximum) is for dehydration of the sample, next (max. in $483{ }^{\circ} \mathrm{C}$ on DSC curve) is for organic matter combustion with overlapping pyrite decomposition. The third step of high mass loss is endothermic carbonates decomposition reaction. The last exothermic peak is derived from spinel phases crystallisation

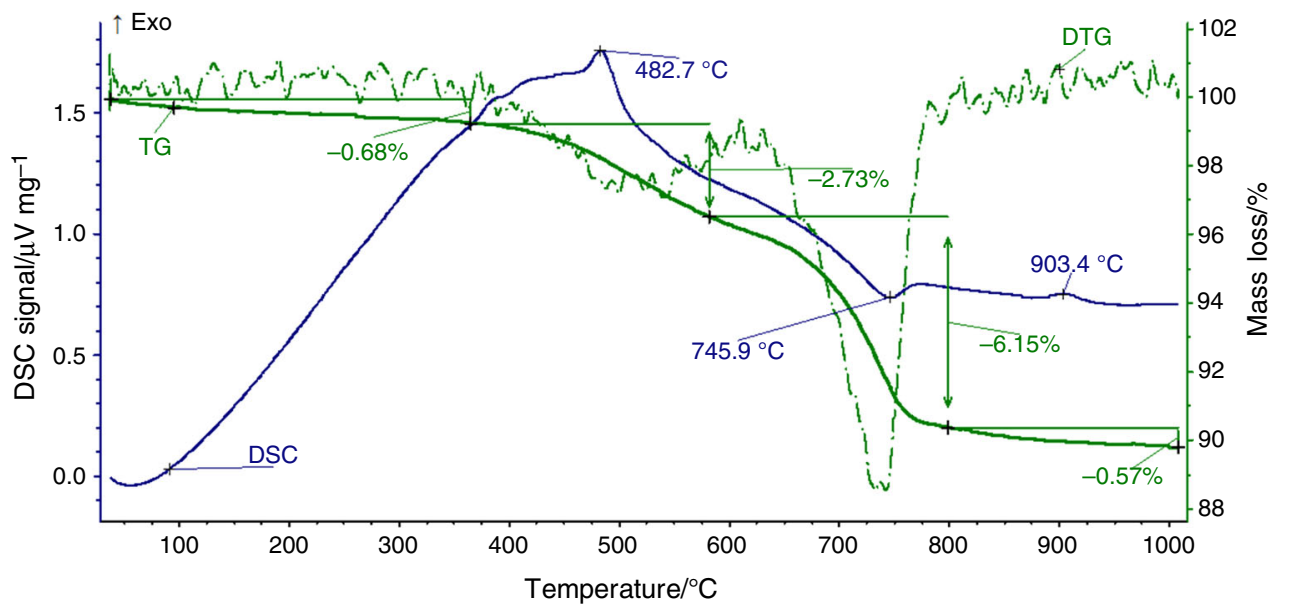

temperature of pyrolysis effect falls on $500-550{ }^{\circ} \mathrm{C}$, depending on the maturity of organic matter.

The last part of DSC curve (above $550-650{ }^{\circ} \mathrm{C}$ ) shows the endothermic peak related to clay minerals dehydroxylation. In some cases, these peaks are overlapped by the effect of oxidation or pyrolysis of the remainder of organic matter. The research results obtained by Yariv [12] show that the dehydroxylation temperature in case of organoclay mixture is sometimes lower than in case of pure clay materials, but the reason of this shift is unknown.

The quartz presence in the rock can be easily observed on DSC curves in the form of a small endothermic effect, with maximum at $573{ }^{\circ} \mathrm{C}$. It is known as "quartz peak" and attributed to quartz $\beta-\alpha$ polymorph transition. The reversible exotherm upon cooling is observed at the same temperature. This polymorph transition is not connected to the mass change; hence, the quantitative quartz determination in the sample is not possible. It could be only roughly estimated by the intensity of peak on DSC line [16]. Dubrawski and Warne [17] stated the possibility of quartz determination in the composed sample, when this mineral is present in amounts of 5-50\%. Comparing the results of XRD analysis we can conclude that in the case of present study, quartz is not detectable under the amount of $28 \%$. Studied shale rocks are the mixtures of minerals, what could interfere the DSC signal, but the presence of quartz is expected to be visible on DSC curve under cooling conditions, as it was mentioned above. The low level of the quartz detectability is rather a consequence of a very finegrained structure of the investigated rocks. The small quartz particle size results in that they are significantly dispersed in the rock, which in turn effectively yield no thermal inversion [18].

\section{Organic matter and pyrite content}

A comparison of the reactions occurring in an oxidising and inert atmosphere can give a solution to the problem of some effects overlapping. The example of sample 1 (Fig. 3) demonstrates DSC/TG/DTG curves for oxidising 
Table 2 TG/DSC results for the examined rocks

\begin{tabular}{|c|c|c|c|c|c|c|}
\hline \multirow[t]{2}{*}{ Sample } & \multicolumn{3}{|l|}{ Oxidising atmosphere } & \multicolumn{3}{|l|}{ Inert atmosphere } \\
\hline & Reaction & $\begin{array}{l}\text { Temperature } \\
\text { range } /{ }^{\circ} \mathrm{C}\end{array}$ & $\begin{array}{l}\text { Mass } \\
\operatorname{loss} / \%\end{array}$ & Reaction & $\begin{array}{l}\text { Temperature } \\
\text { range } /{ }^{\circ} \mathrm{C}\end{array}$ & $\begin{array}{l}\text { Mass } \\
\operatorname{loss} / \%\end{array}$ \\
\hline \multirow[t]{4}{*}{1} & Clay minerals dehydration & $40-/ 115 /-218$ & 0.46 & Clay minerals dehydration & $40-280$ & 0.38 \\
\hline & Pyrite decomposition & $\begin{array}{l}388-/ 453 \\
481 /-550\end{array}$ & 2.97 & Calcite decomposition & $\begin{array}{l}650-/ 730 /- \\
780\end{array}$ & 4.78 \\
\hline & Clay minerals dehydroxylation & $550-650$ & 0.73 & & & \\
\hline & Calcite decomposition & $\begin{array}{l}650-/ 718 /- \\
794\end{array}$ & 2.56 & & & \\
\hline \multirow[t]{2}{*}{2} & Organic matter combustion & $\begin{array}{l}380-1458 /- \\
700\end{array}$ & 0.53 & Pyrolysis & n.o. & n.o. \\
\hline & Quartz transition & 572 & - & Quartz transition & 572 & - \\
\hline 3 & Organic matter combustion & $\begin{array}{l}400-1457 /- \\
560\end{array}$ & $\begin{array}{l}3.27 \\
\text { (total) }\end{array}$ & n.o. & - & $\begin{array}{l}2.05 \\
(\text { total })\end{array}$ \\
\hline \multirow[t]{4}{*}{8} & Clay minerals dehydration & $40-365$ & 0.68 & Clay minerals dehydration & $40-/ 77 /-300$ & 0.37 \\
\hline & $\begin{array}{l}\text { Organic matter combustion with } \\
\text { overlapping pyrite decomposition }\end{array}$ & $\begin{array}{l}365-/ 483 /- \\
580\end{array}$ & 2.73 & Pyrolysis & $\begin{array}{l}380-1520 /- \\
600\end{array}$ & 2.57 \\
\hline & Calcite and dolomite decomposition & $\begin{array}{l}630-/ 746 /- \\
800\end{array}$ & 6.15 & Calcite decomposition & $\begin{array}{l}600-/ 760 /- \\
870\end{array}$ & 5.87 \\
\hline & Spinel phases crystallisation & 903 & - & Spinel phases crystallisation & 900 & - \\
\hline \multirow[t]{3}{*}{$\mathrm{C} 2$} & Clay minerals dehydration & $40-/ 85 /-310$ & 0.87 & Clay minerals dehydration & $40-/ 86 /-310$ & 0.86 \\
\hline & $\begin{array}{l}\text { Organic matter combustion with } \\
\text { overlapping pyrite decomposition }\end{array}$ & $\begin{array}{l}370-/ 516 /- \\
660\end{array}$ & 7.53 & Pyrolysis & $\begin{array}{l}310-/ 520 /- \\
660\end{array}$ & 5.40 \\
\hline & Muscovite dehydroxylation & $\begin{array}{l}660-/ 840 /- \\
1000\end{array}$ & 1.04 & Muscovite dehydroxylation & $660-1000$ & 2.21 \\
\hline \multirow[t]{3}{*}{ C5 } & Clay minerals dehydration & $40-/ 72 /-300$ & 0.85 & Clay minerals dehydration & $40-/ 75 /-300$ & 0.73 \\
\hline & Organic matter combustion & $\begin{array}{l}346-/ 520 /- \\
668\end{array}$ & 5.14 & Pyrolysis & $\begin{array}{l}330-1550 /- \\
709\end{array}$ & 4.11 \\
\hline & Muscovite dehydroxylation & $\begin{array}{l}670-/ 820 /- \\
1000\end{array}$ & 0.74 & Muscovite dehydroxylation & $710-1000$ & 1.43 \\
\hline \multirow[t]{4}{*}{ C11 } & Clay minerals dehydration & $40-/ 80 /-260$ & 0.54 & Clay minerals dehydration & $40-/ 90 /-260$ & 0.66 \\
\hline & Organic matter combustion & $\begin{array}{l}320-/ 514 /- \\
605\end{array}$ & 3.69 & Pyrolysis & $\begin{array}{l}320-/ 477 /- \\
640\end{array}$ & 3.22 \\
\hline & Quartz transition & 571 & - & Quartz transition & 574 & - \\
\hline & Muscovite dehydroxylation & $\begin{array}{l}605-/ 780 /- \\
1000\end{array}$ & 1.06 & Muscovite dehydroxylation & $640-1000$ & 1.24 \\
\hline \multirow[t]{4}{*}{ K1 } & Clay minerals dehydration & $40-/ 77 /-260$ & 0.67 & Clay minerals dehydration & $40-/ 74 /-330$ & 0.81 \\
\hline & Organic matter combustion & $\begin{array}{l}327-/ 480 /- \\
690\end{array}$ & 5.15 & Pyrolysis & $\begin{array}{l}330-/ 522 /- \\
655\end{array}$ & 4.28 \\
\hline & Quartz transition & $\max .572$ & - & Muscovite dehydroxylation & $655-1000$ & 1.35 \\
\hline & Muscovite dehydroxylation & $\begin{array}{l}690-/ 830 /- \\
1000\end{array}$ & 0.59 & & & \\
\hline \multirow[t]{3}{*}{$\mathrm{K} 2$} & Clay minerals dehydration & $40-/ 98 /-290$ & 0.51 & Clay minerals dehydration & $40-/ 84 /-330$ & 0.85 \\
\hline & Organic matter combustion & $\begin{array}{l}290-/ 498 /- \\
680\end{array}$ & 6.46 & Pyrolysis & $\begin{array}{l}330-/ 526 /- \\
633\end{array}$ & 5.72 \\
\hline & Muscovite dehydroxylation & $680-1000$ & 0.63 & Muscovite dehydroxylation & $633-1000$ & 2.46 \\
\hline \multirow[t]{3}{*}{ P1 } & Clay minerals dehydration & $40-/ 93 /-210$ & 0.51 & Clay minerals dehydration & $40-/ 80 /-180$ & 0.76 \\
\hline & Organic matter combustion & $\begin{array}{l}325-/ 535 /- \\
715\end{array}$ & 6.59 & $\begin{array}{l}\text { Pyrolysis with overlapping } \\
\text { muscovite dehydroxylation }\end{array}$ & $\begin{array}{l}310-1510 /- \\
715\end{array}$ & 5.69 \\
\hline & Muscovite dehydroxylation & $\begin{array}{l}715-/ 858 /- \\
1000\end{array}$ & 0.42 & & & \\
\hline
\end{tabular}


Table 2 continued

\begin{tabular}{|c|c|c|c|c|c|c|}
\hline \multirow[t]{2}{*}{ Sample } & \multicolumn{3}{|l|}{ Oxidising atmosphere } & \multicolumn{3}{|l|}{ Inert atmosphere } \\
\hline & Reaction & $\begin{array}{l}\text { Temperature } \\
\text { range } /{ }^{\circ} \mathrm{C}\end{array}$ & $\begin{array}{l}\text { Mass } \\
\text { loss } / \%\end{array}$ & Reaction & $\begin{array}{l}\text { Temperature } \\
\text { range } /{ }^{\circ} \mathrm{C}\end{array}$ & $\begin{array}{l}\text { Mass } \\
\text { loss } / \%\end{array}$ \\
\hline \multirow[t]{4}{*}{ Q22 } & Clay minerals dehydration & $40-/ 80 /-240$ & 1.03 & Clay minerals dehydration & $40-/ 90 /-240$ & 1.69 \\
\hline & Pyrite decomposition & $\begin{array}{l}380-/ 415 /- \\
450\end{array}$ & n.o. & Pyrolysis & $\begin{array}{l}366-/ 500 \\
556 /-610\end{array}$ & 4.65 \\
\hline & Organic matter combustion & $\begin{array}{l}400-/ 480 \\
544 /-635\end{array}$ & 4.76 & Clay minerals dehydroxylation & $610-1000$ & 1.47 \\
\hline & Clay minerals dehydroxylation & $635-1000$ & 1.64 & & & \\
\hline \multirow[t]{4}{*}{ R4 } & Clay minerals dehydration & $40-235$ & 0.55 & Clay minerals dehydration & $40-/ 80 /-230$ & 0.67 \\
\hline & Organic matter combustion & $\begin{array}{l}235-/ 456 /- \\
645\end{array}$ & 6.36 & $\begin{array}{l}\text { Pyrolysis + clay minerals } \\
\text { dehydroxylation }\end{array}$ & $\begin{array}{l}350-1500 /- \\
640\end{array}$ & 5.14 \\
\hline & Clay minerals dehydroxylation & $\max .498$ & & Muscovite dehydroxylation & $640-1000$ & 1.70 \\
\hline & Muscovite dehydroxylation & $\begin{array}{l}645-/ 800 /- \\
1000\end{array}$ & 0.93 & & & \\
\hline R5 & $\begin{array}{l}\text { Organic matter combustion and other } \\
\text { overlapping reactions }\end{array}$ & $\begin{array}{l}320-/ 454 /- \\
609\end{array}$ & 10.29 & Pyrolysis & $\begin{array}{l}318-/ 503 /- \\
616\end{array}$ & 4.95 \\
\hline
\end{tabular}

n.o. determination not possible

atmosphere (fine lines), and the corresponding curves for inert atmosphere (bold lines). Apart from dehydration reactions, present below the temperature of $150{ }^{\circ} \mathrm{C}$, the clearly visible for an inert atmosphere is the endothermic reaction in the temperature range of $650-780{ }^{\circ} \mathrm{C}$. This reaction is attributed to calcite decomposition, and it is also detectable under the oxidising atmosphere. The most relevant for this example is the lack of pyrolysis effect, which indicates the lack of organic matter in this sample (which is also confirmed by very low TOC in this sample-0.04\%). This means that the exothermic reaction appearing on a DSC curve for oxidising atmosphere reflects the oxidation reaction of pyrite. Pyrite decomposition is a complex reaction dependent on pyrite content in the sample, the oxygen content in the environment, etc. This reaction is expressed here in the form of a double exothermal peak (453 and $481^{\circ} \mathrm{C}$ ). In nitrogen atmosphere, only the endothermic pyrite disproportion reaction can be recorded between 600 and $700{ }^{\circ} \mathrm{C}$. This reaction is overlapping the mentioned calcite decomposition. This explains the greater mass loss for calcite decomposition in inert atmosphere.

Ysupova et al. [19] stated the great advantage of thermal methods in allowing not only concentrated organic matter (OM) but also finely dispersed $\mathrm{OM}$ to be detected and
Fig. 3 DSC, TG and DTG curves for sample 1. Fine lines relate to the reaction in an oxidising atmosphere (air), while bold lines relate to inert atmosphere (nitrogen)

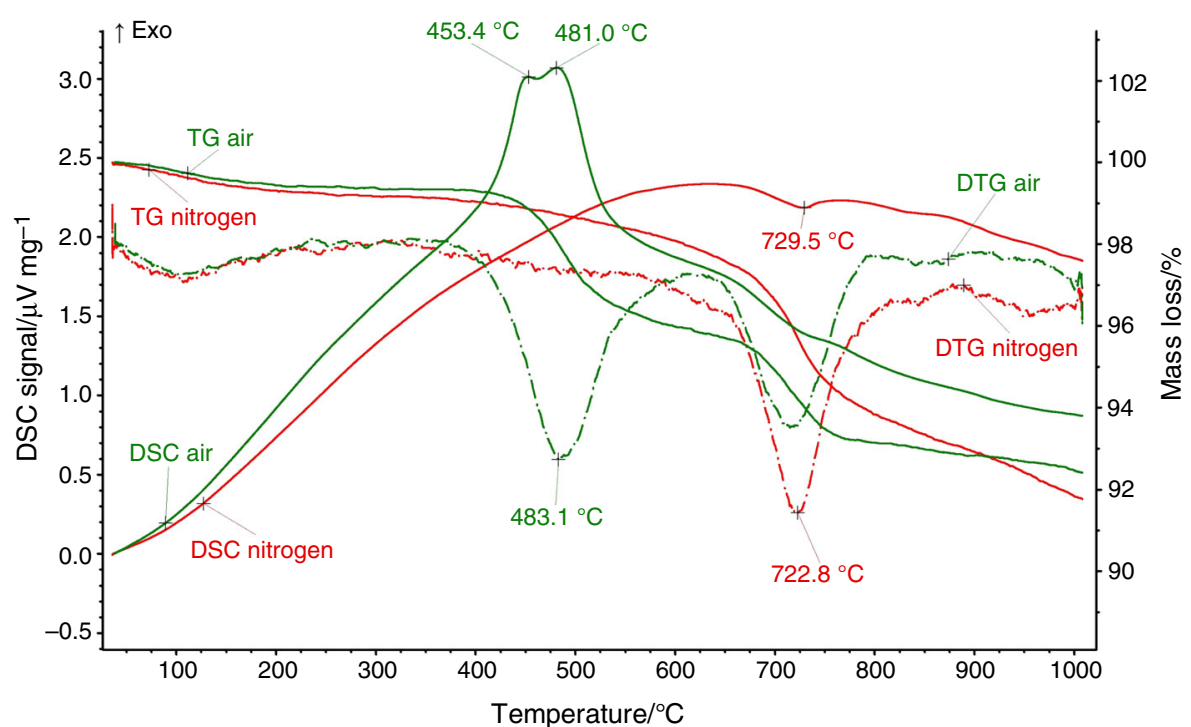


examined. These authors found that the organic matter concentration even below $0.25 \%$ is detectable. Ysupova et al. [19] analysed the organic matter in oil- and bitumen-containing rocks, and they found the thermooxidative destruction of $\mathrm{OM}$ starting in the temperature region of $130-200{ }^{\circ} \mathrm{C}$ and ending at $600-700{ }^{\circ} \mathrm{C}$. The mass loss resulted from $\mathrm{OM}$ combustion (under oxidative atmosphere) up to the temperature $500{ }^{\circ} \mathrm{C}$ is regarded by Markova et al. [20] to be related to the presence of light hydrocarbons in bitumens. Schmidt and Heide [9] performed analysis of hydrocarbons in Palaeozoic black shales under vacuum, and stated the bitumen decomposition up to $300{ }^{\circ} \mathrm{C}$, and pyrolysis of the kerogen between 300 and $850{ }^{\circ} \mathrm{C}$. In case of our study, the pyrolysis takes place between 310 and $715^{\circ} \mathrm{C}$. In the tested samples, the presence of bitumines was not stated, as the mass loss in low temperatures is very faint, associated rather with dehydration of the rock. The maximum temperature of the pyrolysis peak, which describes the thermal maturity of the kerogen, is placed between 477 and $550{ }^{\circ} \mathrm{C}$, which indicates kerogen of type II. The resulted mass loss is from 2.6

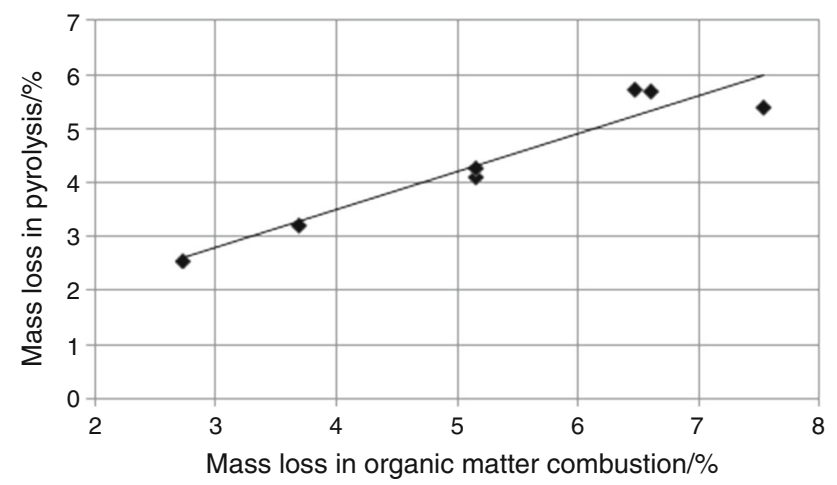

Fig. 4 Relationship between mass loss resulted from organic matter combustion and pyrolysis in examined samples (excluding sample 1, 2 and 3) to $5.7 \%$ (not taking into account samples 1, 2 and 3 where the value is not possible to measure). The mass loss resulted from OM decomposition correlates with the values of TOC. The lowest TOC values were determined for samples 1,2 and $3(0.04-0.37 \%)$. Samples 8 and P1 have the average TOC content (0.63-0.67\%), while samples R4, $\mathrm{R} 5$ and $\mathrm{C} 2$ have comparatively high content of organic carbon (1.38-2.89\%).

The loss in mass resulted from organic matter combustion (under synthetic air environment) is higher in each sample, from 2.7 to $7.5 \%$. There is a strong correlation between mass loss in those two processes (Fig. 4). The ratio of the mass loss during combustion to mass loss as a result of pyrolysis averages: 1.2.

Figure 5 shows DSC curves for all analysed samples of the reaction under oxidative atmosphere. The exothermal effects between 300 and $600{ }^{\circ} \mathrm{C}$ are generally caused by the organic matter combustion. The curves were stacked for easy comparison; hence, the scale of y-axis (DSC) is not shown (it is displaced for each sample).

The absence of the low-temperature peaks (below $300{ }^{\circ} \mathrm{C}$ ) is explained by Cebulak et al. [14] as indicating heating of the rock formation above $200{ }^{\circ} \mathrm{C}$, typical of diagenesis-catagenesis of sediments. The light and middle OM fraction oxidation ( $\operatorname{sharp}$ peak $T_{\max }=415^{\circ} \mathrm{C}$ ) takes place in case of sample Q22, which indicates the low to moderate maturity of kerogen. This sample represents Upper Carboniferous sediment of Lublin Basin. The low maturation of $\mathrm{OM}$ is a consequence of thermal history of the region [21].

The heavy OM fractions are destructed in different ranges of temperature. In case of samples: $2,3,8, \mathrm{~K} 1, \mathrm{~K} 2$, $\mathrm{R} 4$ and $\mathrm{R} 5, T_{\max }$ of OM combustion ranges from 450 to $480{ }^{\circ} \mathrm{C}$, whereas for samples: P1, C2, C5 and C11 from 500 to $580{ }^{\circ} \mathrm{C}$. Sample 1 is not discussed here in terms of the occurrence of organic matter, due to the fact that a strong exotherm is affected by the decomposition of pyrite (which was discussed above-Fig. 3). Samples 2, 3 and 8 represent lower Silurian shales. The other samples in this

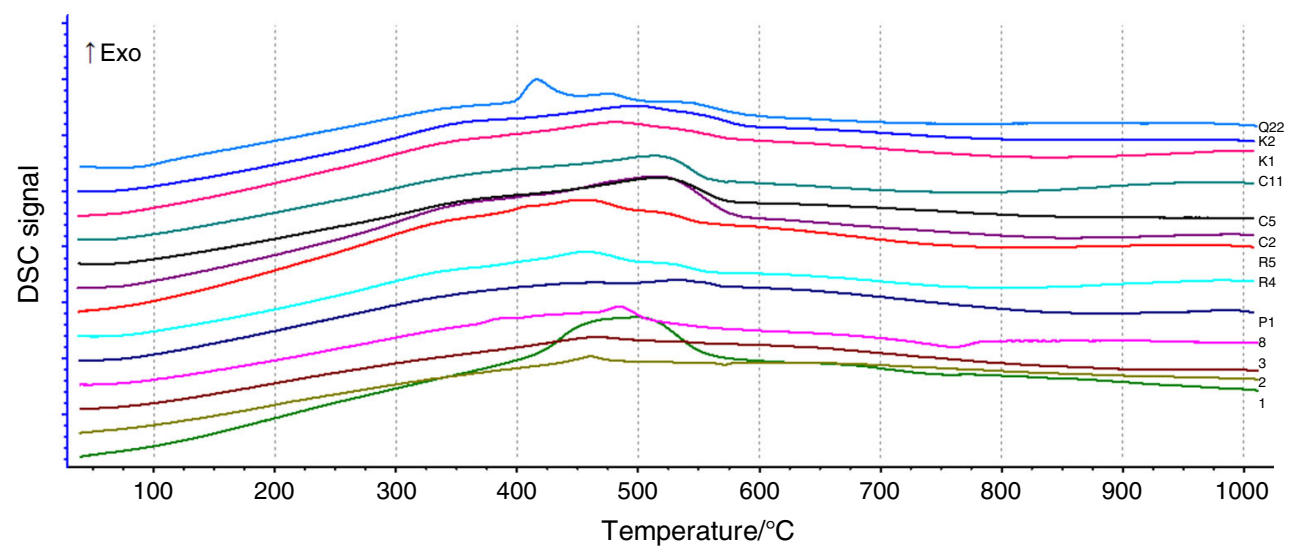

Fig. 5 DSC curves of all investigated samples (oxidative atmosphere) 
group originate from the coal mines located in the southwest part of the Upper Silesia Coal Basin (USCB), representing claystones and mudstones of Carboniferous productive sequence. The high level of organic matter maturity in samples P1, C2, C5 and C11 (from Jastrzębie region) could be explained by the influence of igneous intrusions, causing thermal alteration observed in this region in coal seams and adjacent rocks.

\section{Conclusions}

The performed thermal analysis allowed to detect the presence of some minerals in the analysed fine-grained rocks: clay minerals, muscovite, quartz, calcite, dolomite and pyrite. Quartz is easily detectable by TG/DSC methods in the rock samples, but only if its content exceeds $28 \%$. This is due to the fact that the analysed rocks are the mixtures of minerals of very fine grains, thus causing dispersion and in consequence the low detectability of quartz grains.

A comparison of the reactions occurring in an oxidising and inert atmosphere can give a solution to the problem of some effects overlapping. It is possible to distinguish the superimposed reaction effects of pyrite decomposition and organic matter combustion when comparing DSC/TG curves obtained in oxidising and inert atmosphere.

The analysis of DSC curves of heated rocks under oxidative atmosphere allows to determine the temperature regions of the $\mathrm{OM}$ combustion. The concluded organic matter maturity could be explained by the thermal history of the region. Measured on TG curves, the mass loss resulted from combustion and the mass loss being a result of pyrolysis are strongly correlated.

Acknowledgements The research leading to these results has received funding from the Polish-Norwegian Research Programme, operated by the National Centre for Research and Development under the Norwegian Financial Mechanism 2009-2014, in the frame of Project Contract No. Pol-Nor/196923/49/2013.

Open Access This article is distributed under the terms of the Creative Commons Attribution 4.0 International License (http://creativecommons. org/licenses/by/4.0/), which permits unrestricted use, distribution, and reproduction in any medium, provided you give appropriate credit to the original author(s) and the source, provide a link to the Creative Commons license, and indicate if changes were made.

\section{References}

1. Elbeyli IY, Pişkin S. Combustion and pyrolysis characteristics of Tunçbilek lignite. J Therm Anal Calorim. 2006;83:721-6.

2. Śmieja-Król B. Analysis of organic matter from Witwatersrand Basin (South Africa) by OTA and Py-GC-MS. J Therm Anal Calorim. 2003;72:383-91.
3. Deng J, Zhao J, Huang ACh, Zhang Y, Wang CP, Shu ChM. Thermal behavior and microcharacterization analysis of second-oxidized coal. J Therm Anal Calorim. 2017;127: 439-48.

4. Kok MV. Thermal investigation of Seyitomer oil shale. Thermochim Acta. 2001;369:149-55.

5. Warne SSJ, Dubrawski JV. Applications of DTA and DSC to coal and oil shale evaluation. J Therm Anal. 1989;35: $219-42$.

6. Wang Z, Liu X, Wang Y, Liu L, Wang H, Deng S, Sun Y. Studies on the co-pyrolysis characteristics of oil shale and spent oil shale. J Therm Anal Calorim. 2016;123:1707-14.

7. Rajeshwar K. Thermal analysis of coals, oil shales and oil sands. Thermochim Acta. 1983;63:97-112.

8. Rajeshwar K. Calorimetric response of fossil fuel systems: prospects and problems. In: Johnson JF, et al., editors. Analytical calorimetry. New York: Plenum Press; 1984. p. 113-31.

9. Schmidt CM, Heide K. Thermal analysis of hydrocarbons in Paleozoic black shales. J Therm Anal Calorim. 2001;64: 1297-302.

10. Marshall CP, Kannangara GSK, Wilson MA, Guerbois JP, Hartung-Kagi B, Hart G. Potential of thermogravimetric analysis coupled with mass spectrometry for the evaluation of kerogen in source rocks. Chem Geol. 2002;184:185-94.

11. Cebulak S, Gawęda A, Langier-Kuźniarowa A. Oxyreactive thermal analysis of dispersed organic matter, kerogen and carbonization products. A tool for investigation of heated rock masses. J Therm Anal Calorim. 1999;56:917-24.

12. Yariv S. Differential thermal analysis (DTA) of organo-clay complexes. In: Smykatz-Kloss W, Warne SSJ, editors. Lecture notes in earth sciences 38. Thermal analysis in the geosciences. Berlin: Springer; 1991. p. 328-51.

13. Paulik J, Paulik F, Arnold M. Simultaneous TG, DTG, DTA and EGA technique for the determination of carbonate, sulphate, pyrite and organic material in minerals, soils and rocks. Part I. Principles of the method. J Therm Anal Calorim. 1982;25:32740.

14. Cebulak S, Karczewska A, Mazurek A, Langier-Kuźniarowa A. Kerogen as a geochemical marker of the thermal history of rocks. J Therm Anal. 1997;48:163-75.

15. Földvári M. Handbook of thermogravimetric system of minerals and its use in geological practice. Occasional papers of the Geological Institute of Hungary, vol. 213; 2011.

16. Smykatz-Kloss W. Differential thermal analysis: application and results in mineralogy. Berlin: Springer; 1974.

17. Dubrawski JV, Warne SSJ. The application of differential scanning calorimetry to mineralogical analysis. Thermochim Acta. 1986;107:51-9.

18. Dubrawski JV. Differential scanning calorimetry and its application to mineralogy and the geosciences. In: SmykatzKloss W, Warne SSJ, editors. Lecture notes in earth sciences 38. Thermal analysis in the geosciences. Berlin: Springer; 1991. p. 16-59.

19. Ysupova TN, Petrova LM, Mukhametshin RZ, Romanov GV, Foss TR, Ganneva YM. Distribution and composition of organic matter in oil- and bitumen-containing rocks in deposits of different ages. J Therm Anal Calorim. 1999;55:99-107.

20. Markova K, Elui N, Šiškov G. DTA and TG studies of Paleocene bituminous rocks from El Iusr oil deposit-Egypt. J Therm Anal Calorim. 1997;48:331-41.

21. Botor D, Kotarba M, Kosakowski P. Petroleum generation in the Carboniferous strata of the Lublin Trough (Poland): an integrated geochemical and numerical modelling approach. Org Geochem. 2002;33:461-76. 